\title{
Shoppers Perception of Retail Service Quality: Supermarkets versus Small Convenience Shops (Dukas) In Kenya
}

\author{
Sarah Wambui Kimani (Corresponding author) \\ The Catholic University of Eastern Africa, \\ P. O. Box 62157, 00200, Nairobi, Kenya
}

Tel: +254-716-641-262Ｅ-mail: swambui@cuea.edu, swambuikimani@yahoo.com

\author{
Elias Kiarie Kagira \\ Department of Business Administration, \\ Africa Nazarene University (Kenya), \\ P.O. Box -53067 Nairobi, Kenya, \\ Tel: +254- 713-209-606_E-mail: ekiarie@anu.ac.ke, kkagira@yahoo.com \\ Lydia Kendi \\ Department of Educational Psychology, \\ Kenyatta University (Kenya) \\ P.O. Box 43844 Nairobi, Kenya, \\ Tel: +254-723- 835-188Ｅ-mail: lkendiuk@yahoo.co.uk \\ Cleophas Muhavini Wawire \\ The Catholic University of Eastern Africa, \\ P. O. Box 62157, 00200, Nairobi, Kenya \\ $\&$ \\ Universit'e Joseph Fourier (Grenoble I), \\ 301 rue de la Chimie, BP 53, \\ F-38041 Grenoble Cedex 9, France \\ Tel: +254-721-720-423Ｅ-mail: muhavini@yahoo.com,muhavini@cuea.edu
}

Received: April 14, 2011

doi:10.5430/jms.v3n1p55
Accepted: December 21, 2011 Published: February 15, 2012

URL: http://dx.doi.org/10.5430/jms.v3n1p55

\begin{abstract}
The purpose of this paper was to determine shoppers perceptions of service quality offered in Kenyan supermarkets and very small convenience shops. A cross sectional design of explorative nature was adopted for this study to evaluate the shoppers' perception of the convenience shops and supermarkets. Data from semi-structured questionnaire was analyzed using factor analyses and Pearson correlation analysis. Factor analysis revealed the following as important factors that customers of convenience shops (Kiosk/Dukas) considered and arranged in order of importance are: (1) ability to solve their problems (2) physical facilities and displays (3) assistance/helping the customer (4) variety and deep assortment (5) cleanliness (6) accurate records (7) responsiveness-dealing with complaints efficiently and promptly (8) appearance (9) individualized attention and (10) convenience. These factors were further condensed into three factors namely; tangibles, responsiveness and reliability. The important factors considered by customers of supermarkets, arranged in order of importance include: (1) courtesy (2) physical facilities and displays (3) accurate records (4) individualized attention (5)
\end{abstract}


competence (6) keeping promises (7) variety and deep assortments (8) prompt service (9) neat appearance and (10) accessibility. These factors were further condensed into four factors namely; reliability, responsiveness, empathy and tangibles. The overall level of satisfaction with the convenience shops (Dukas) compared to the supermarket was a mean score of 2.74 , on a five point scale, indicating a positive level of satisfaction. Pearson correlation analysis indicated a significant positive correlation between level of satisfaction and recommending a friend to the outlet. This research was only a pilot study with limitations on sample size and geographical scope. The study concentrated on only two sub-urban areas of Nairobi (Ongata Rongai and Ngong areas) thus limiting the generalization of the findings. The list of factors identified in this study can be used by both the small convenience shops and supermarkets to determine whether they are allocating their efforts in the areas that are considered important by the shoppers. It could also be used as a guideline for resource allocation, financial or otherwise. This study provides a useful guide to research into service quality within retail sector. The study identified important factors that shoppers considered important in their perception. Article type: Research paper

Keywords: Service Quality, Perception, Satisfaction

\section{Introduction}

Retailing services have become very important today in many economies. The retailing industry plays a crucial role in the overall economy of Kenya contributing $10 \%$ to GDP and an estimated total wage payment of Ksh. 86.7 million within the private sector in 2009 (Economic Survey, 2010). Over the last fifteen years, the Kenyan retailing industry has experienced phenomenal growth with major retailers expanding to the broader East Africa and beyond. Retailers have positioned themselves for all kind of customer needs and income levels especially the growing young working population. Many retailers have been upgrading themselves by re-locating to up-coming modern malls and shopping centers, providing superior shopping atmosphere and experience especially in the urban and semi urban centers. However, it is not clear whether these retailers have fully embraced the retail concept which emphasis on proper communication, total retail experience, customer service, relationship retailing and consistent strategy. In addition, the retail sector in Kenya should embrace the marketing orientation perspective basically applicable to any retailer. In this, the marketing decisions revolving around the target market, product assortment, services and store atmosphere, store activities and experience, procurement, price decisions, communications and location decisions which are very critical to a retailer's success should be emphasized (Kotler \& Keller, 2006).

\subsection{Importance of Service Quality within the Retail Outlets}

The growth in importance of service quality has been influenced greatly by the changing nature of the world economies and the customers changing needs, tastes and preferences. The move has also been fueled by the growth in consumerism, world travel and the competitive business environments. Perez et al. (2007) observed that service quality has become a critical factor in enabling firms to achieve a differential advantage over their competitors and thus, it makes a significant contribution to profitability and productivity. Indeed, service quality has become a key concept in a competitive corporate strategy (Gronroos, 2001). Zeithaml, Parasuraman and Berry (1988), identified two major payoffs of quality; Quality creates true customers and that it leads to efficiencies. Excellent service pays off because it creates true customers who are like annuities. They keep pumping revenues into an organization. Quality improvements lead to operational efficiencies beyond those associated with scale economies. This is because, quality improvements, (both in products and services) lowers defects, service errors and customer complaints. Thus service quality does pay. Customer service satisfaction depends on the quality of service customers' receive and how well this matches their expectations. Factors such as age, gender, income, level of education may shape these expectations (Gagliano \& Hathcote, 1994). Many retail service outlets in Kenya are characterized by long waits (especially at month-end) and impolite employees who always seem overworked and who may have little or no product knowledge. Realizing the rising importance of quality service and customer care, many retailers are improving their service strategies.

\section{Problem Statement}

In the last decade, many firms have come to realize that understanding, meeting and anticipating customer needs is probably the most important source of sustained competitive advantage (Vilares \& Coelho, 2003). In-depth knowledge of how to satisfy customers is particularly important in developing countries such as Kenya, where small convenience stores are struggling to compete with large supermarkets that are expanding to sub-urban areas and elsewhere. To gain competitive advantage and increase organizational effectiveness, it is paramount to focus attention on improving service quality as a way of differentiation. Excellent customer service may indeed be the best answer to countering the increasing trend of the expansion of supermarkets. The retailing sector has been the focus of much academic research and considerable attention has been directed to the way consumers think and feel about stores making up their attitudes and perceptions towards the stores. Tan and Mehta (1994) researched on the relative role in consumer choice of 
supermarkets in Singapore, Ed Watkins (1976) researched on factors influencing choice of supermarkets and convenience stores to develop a marketing strategy for each, while Ryu and Han (2010) investigated the influence of quality food, service and physical environment on customer satisfaction and behavioral intention in quick-casual restaurants in Midwestern state. In spite of these efforts, research on perception of service quality within convenience shops and supermarkets in Kenya is scanty. Hence, the assessment of shoppers' perceptions of service performance within the retail stores is pertinent and timely because perceived performance could influence the retail stores image, shopper satisfaction and bottom-line growth. The purpose of this study was to assess shoppers' perceptions of the quality of service provided by the small convenience shops (Dukas) and the supermarkets in Kenya. Specifically, this research hoped to find answers to the following questions:

1. What do shoppers generally consider important while shopping in a retail store?

2. What are the important factors of retail service quality (convenience shops and supermarkets)?

3. What can be suggested in order to improve the retail businesses?

\section{Review of Literature}

Retailers provide a combination of goods and services to their customers. Retailing has been characterized as a service with high degree of labour intensity, and low degree of interaction and customization (Tan \& Mehta, 1994). Examples of retailers in Kenya include the supermarkets, kiosks (very small convenience stores), hawkers, butcheries, fuel stations, bookshops, hotels, chemists, banks, ordinary shops, auto dealers, cloth stores, jewelry stores, gift shops, shoe stores, furniture stores, music stores and hair salons among others (Kagira \& Kimani, 2010). While the traditional marketing emphasis in retailing has been on product quality (goods), growing research in service quality has made many retailers to understand the importance of service quality in their retail offerings (Bougoure \& Lee, 2009). As mentioned earlier, positive customer perception of service quality can greatly influence a firm’s performance and competitiveness.

\subsection{Customer Perception and Retail Image}

Customer perception has been defined as a customer's overall impression of the relative inferiority/superiority of an organization and its services (Bitner \& Hubbert, 1994). This perception is influenced by many factors such as employees performance, facilities, price of products and quality of service offered among other factors (Gagliano \& Hathcote, 1994; Naylor \& Frank, 2000; Sheinin \& Wagner, 2003;Shaw \& Haynes, 2004). Further, due to technological developments, affluence and rise in levels of education, customers perceptions are greatly changing calling for organizations to have concerted effort to understand these perceptions. Retail image on the other hand refers to how a retailer is perceived by customers and other parties. Numerous factors contribute to a retail image. According to Berman and Evans (2005) overall retail image is influenced by store location, merchandise attributes, pricing, firm's positioning, customer service, target market, attributes of physical facilities, shopping experience, promotion tools (such as advertising, public relations, personal selling, sales promotion) and community service. Further, Berman and Evans (2005) note that a retailer's image depends heavily on its 'atmosphere' or the psycho-logical feeling a customer gets when in that retail outlet.

Literature on store image treats merchandise quality and variety, service quality, store atmosphere and physical environment as key store image attributes.

\subsection{Measuring Retail Service Quality}

Service quality in retail outlets is different from other product or service oriented organizations (Finn, 2004). This is because of the unique nature of retail organizations which offer both goods and services. A review of service quality scales of retail stores by Wang (2003) indicates that the two most widely used scales are the SERVQUAL (Service Quality) developed by Parasuraman, Berry and Zeithaml, (1988) and RSQS (Retail Service quality Scale) developed by Dabholkar, Thorpe and Tentz (1996). On the application of SERVQUAL within retail setting, Wang (2003) notes that SERVQUAL fails to provide an accurate and effective measure of service quality in retail settings such as discount stores and apparel specialty stores that offer a mix of goods and services. Further, Wang found that there is a wide variety of empirical factor structures that can be obtained which vary in terms of interpretability thus differing from five factor structure (Reliability, Assurance, Tangibility, Empathy, Responsiveness) proposed by Parasuraman, Berry and Zeithaml (1988). Studies using RSQS in Vietnam (Nguyen \& Le Nguyen, 2007) did not meet discriminant validity on two factors, the personal interaction and problem solving. Further the scale was refined to four component construct consisting of service personnel, physical aspects, policy and reliability. Based on this, Nguyen and Le Nguyen (2007) caution the use of RSQS within the supermarkets and calls for its adaptation. Further, Wang (2003) proposes the development of a new, more reliable, culturally bounded and accurate measure of retail service quality which can be applied globally but also helpful to retail managers in more accurate assessment of service quality within retail stores. 


\subsection{Dimensions of Service Quality in Retail Outlets}

Dabholkar et al. (1996) developed a retail service quality model (RSQS) and identified five dimensions important in a retail set up. These dimensions are; (1) physical aspects which includes the store appearance and store layout; (2) Reliability which evaluates how well retailers keep their promises and do the right things; (3) personal interaction, assessing the retail store personnel in terms of courtesy, helpfulness, and inspiring confidence in customers; (4) problem solving, the ability of retail store personnel to handle returns and exchanges, solve customer problems and complaints; and (5) policy on merchandise quality, parking, operation hours and credit cards. On their part, Turley and Fugate (1992), as quoted by Tan and Mehta (1994) identified five dimensions associated with facility intensive services (such as offered in supermarkets) as: 1) operational dimension, 2) the location dimension, 3) the atmospheric and image dimension, 4) the consumer use dimension and the 5) contact personnel dimension. They contend that satisfaction with the facility driven service usually depends on the customer's ability to interact with the facility in order to produce a satisfactory consumption experience. Writing on the same vein, Strickland (2008) noted that customers have two levels of expectations: desired and acceptable levels. She further advises that for an organization to achieve the range between acceptable and desired, it has to establish: product and service quality specifications, employee performance metrics, product performance and quality metrics, clear definitions of customer expectations, service process management, service process metrics, on-going interactive customer orientation, iterative process monitoring, controls and corrective action procedures. In line with this, Zeitham, Bitner and Glemler (2009) argue that perceptions of service quality are the results of consumer's comparisons of expected service with perceived service. They contend that the gaps between expected and actual/delivered service creates dissatisfaction. Thus, the retailers challenge is to minimize the gaps between expected and actual by first understanding customers' expectation and then delivering those expectations.

\subsection{Factors Influencing Choice of Supermarkets}

Survey of customer analysis and market strategy on supermarkets and convenience stores by Ed Watkins (1976) found that the factors that determined selection of a supermarket by customers were (1) prices (2) cleanliness (3) food quality (4) variety (5) store location (6) employee attitude (7) meat quality (freshness) (8) produce quality (freshness) and (9) store atmosphere. Watkins however notes that the relative importance of all store factors identified by supermarket customers shifted over time and between trading areas due to economic competitive changes and shifts in customer's priorities. The factors of less importance in the customers' choice of a supermarket arranged in a descending order were store layout, services, checkout, specials offers, displays, well stocked, brands available, parking, advertising, product availability and hour open. Other factors identified as important in choice of supermarkets in Singapore by Tan and Mehta (1994) were (1) physical environment which related to variables such as store decor, lighting, ambience and layout, air conditioning, attractiveness of displays and advertising effectiveness; and (2) merchandise and operations consisting mainly of variables relating to the tangible offerings of the supermarkets such as variety and quality of merchandise, availability of desired product lines and desired package sizes. Other variables included in this factor were operational issues such as fast check-out service, ease of return of merchandise and low prices compared with other stores. The third factor (3) was staff which included variables relating to the helpfulness, friendliness, courtesy and training of staff and personalized relations with staff. The fourth (4) factor was issues related to price promotions and included variables related to 'sale' items such as selection/choice, discounts, and availability. The fifth (5) factor related to availability of the supermarket to include variables such as store hours and convenience. The sixth (6) factor related to shopping ease to include ease of movement in the store and ease of finding items; while the seventh (7) factor was the image relating to reliability and reputation of the store.

\subsection{Factors Influencing Choice of Convenience Stores}

Ed Watkins (1976) identified six important factors in the choice of convenience stores and arranged in order of importance as: (1) quick service (2) hours open (3) location (4) products available (5) employee attitude and (6) parking space. Unlike the supermarkets, Watkins noted that the relative importance of these factors associated with convenience stores does not appear to shift significantly over time or between trading areas. However, very few customers identified convenience stores as their primary source of food but were identified as a source for fill-in items.

\section{Methodology}

A cross sectional design of exploratory nature was adopted for this pilot study to determine the shoppers' perception of the small convenience shops and supermarkets. Data was collected by means of a structured questionnaire. Variables in the questionnaire were largely borrowed from Parasuraman et al $(1989,1991)$ SERVQUAL scale which was adapted to local context. The Population of study comprised shoppers of convenience stores and supermarkets in Rongai and Ngong areas of Kajiado district in Kenya. A total of 120 respondents were targeted for this pilot study. Respondents were selected from four different areas (two in Rongai and two in Ngong). Each area with a target of 30 respondents. The 
residential areas were conveniently chosen from Rongai and Ngong areas. One area near a supermarket and the other away from the supermarket (near slum areas). Since the purpose was to compare the shoppers' perceptions between supermarkets and dukas, the shoppers had to be purposively chosen. That is, participating areas and respondents were selected because they were identified as being 'rich' in data about which the study was interested (Easterby-Smith et al., 1991). As purposive sampling is appropriate when the aim of research is to generate an understanding of an under-researched topic rather than confirm or refute hypotheses, it was identified as appropriate for identifying participating areas and respondents.

A pre-testing of the questionnaire was done with 15 respondents at Rongai. This helped to check for any perceived ambiguity, omissions or errors. The researcher personally collected the data and this validates the results. A face to face questionnaire administration was applied to shoppers outside the supermarket and convenience shops. This was done on different days and at different hours of the week to enhance the representativeness of the sample. The five dimensions important in a retail set up identified by Dabholkar et al. (1996) and used in the developed retail service quality model (RSQS) were well articulated in the questionnaire but contextualized for ease of understanding by the shoppers. These variables were integrated and were tested using a five point likert scale.

\subsection{Data Analysis}

The Pearson correlation coefficient was used to determine the nature of relationship between level of education and perception, income levels and perception, gender and perception, age and perception, etc. Factor analysis was used to establish important dimensions or factors in convenience stores’ and supermarkets' service quality.

\section{Results and Discussions}

Out of a total of 120 respondents targeted for the study, only 74 questionnaires were considered for analysis giving a response rate of $62 \%$. The respondents interviewed comprised 49 females and 25 males. Majority of the respondents (50\%) aged between 21-30. Most of them (54\%) earned monthly income of less than 10,000. On the level of education, $31 \%$ had attained O-level education (12 years of schooling comprising primary and secondary levels), 24\% had a diploma while $20 \%$ had primary school education of class five to class eight.

Most respondents (72\%) did their shopping in the supermarkets while only 31\% did it in small convenience shops (kiosks). The rest 3\% did their shopping in hypermarkets. The high preference for supermarkets cuts across the different levels of education except those in the category of primary school class 5-8 where 67\% preferred to shop in the kiosk. Those in the category of lower primary (class 0-4) were indifferent, that is could shop in either the supermarket or the small shops (Kiosk/Duka). Respondents in general cited the following reasons arranged in order of importance for shopping wherever they did (Table 1): 1) Variety, 2) convenience, 3) good communication to customers, 4) less expensive/cheap prices, 5) quick or prompt service, 6) reliability and consistency of service and products, 7) deep assortment of products, 8) courtesy and friendliness, 9) honest, trust and confidence and 10) access or ease of approach and contact. The importance however varied according to levels of education with those with lowest levels of education indicating convenience as an important reason for their shopping, those of standard 5-8 indicated good communication and cheap prices as most important reasons. Those with O-level education indicated good communication, variety and convenience as most important; A-level (beyond 12 years of schooling but not formally trained) group indicated variety, convenience, cheap prices, reliability and consistency of service and products and deep assortment as important reasons for shopping. Those with diploma indicated convenience and variety; bachelor's degrees holders indicated convenience, variety, and cheap price as reasons for their shopping; those with masters indicated variety, convenience, good communication, prompt service and honest trust and confidence while those with $\mathrm{PhD}$ indicated variety as a major reason for their shopping.

Factor analysis revealed the following as important factors that customers of convenience shops (Kiosk/Dukas) considered arranged in order of importance (Table 2): (1) ability to solve their problems (2) physical facilities and displays (3) assistance/helping the customer (4) variety and deep assortment (5) cleanliness (6) accurate records (7) responsiveness dealing with complaints efficiently and promptly (8) appearance (9) individualized attention (10) convenience. The factors of courtesy, communication, prompt service and competence were not considered important by these shoppers. However, further rotation of the above factors and a selection of eigen values greater than 1 (one) yielded three principal components that explained $60.7 \%$ of the total variability thus reducing the factors from 10 to 3 with only 39.3\% loss of information (Table 5). Borrowing from Parasuraman et al. (1998, 1991) condensed five categories of service quality, listed in order of importance; Tangibles, Reliability, Responsiveness, Assurance and Empathy; The three factors can be labeled as tangibles, responsiveness and reliability. Table 5 on the rotated sums of squared loadings shows that the rotation maintains the cumulative percentage of variation explained by the extracted factors but the variation is now more evenly spread over the three components (factors). The large change in the 
individual totals suggests that the rotated component matrix is easier to interpret than the un-rotated matrix. Factor (1)Tangibles (shoppers agreed that the dukas provided variety and deep assortment of products, were visually appealing, neat appearance of the attendant, provided prompt service, gave caring and individualized attention, had business knowledge and were easily accessible). The second factor (2) was labeled Responsiveness (shoppers agreed that the duka/kiosk attendants were always polite and courteous, had convenient operating hours, showed sincere interest in solving customers problems, dealt with complaints efficiently and promptly, kept promises and communicated well). The third factor (3) was labeled Reliability (shoppers agreed that the kiosk attendants kept accurate records). The analysis of the results showed that the three factors had different degrees of importance/weights with Tangibles being the most important factor followed by Responsiveness and Reliability in that order.

The important factors considered by customers of supermarkets in general, arranged in order of importance include (Table 3): (1) courtesy (2) physical facilities and displays (3) accurate records (4) individualized attention (5) competence (6) keeping promises (7) variety and deep assortments (8) prompt service (9) neat appearance and (10) accessibility. Other factors that were not considered as important were quick response to complaints and inquiries, sincere interest in solving their problems, convenience and communication. Table 7 shows the cumulative percentage of variation explained by the extracted factors but the variation is now more evenly spread over the four components (factors).

The four factors could adequately represent the data with a total variance of $64.3 \%$. The first factor (1) was labeled Reliability (supermarket shoppers agreed that the supermarkets provided variety and deep assortment of products, were visually appealing, had convenient operating hours, and kept accurate records). The second factor (2) was labeled Responsiveness (shoppers agreed the supermarkets provided prompt services, had courteous employees, and provided caring and individualized attention). The third factor (3) was labeled Empathy (Shoppers agreed that employees showed a sincere interest in solving their problems, dealt with complaints efficiently and promptly, kept their promises, communicated well and had good knowledge of the business). The fourth factor (4) was labeled Tangibles (shoppers agreed that supermarket employees are normally well dressed and appeared neat). These factors had different weights/importance with Reliability being the most important, followed by Responsiveness, Empathy and Tangibles in that order.

The above findings indicate a lot of similarities on important factors perceived by the two categories of consumers. Thus the service quality dimensions of supermarkets and small convenience shops are not perceived differently in Kenya among different shoppers. The overall level of satisfaction with the convenience shops (Dukas) compared to the supermarket was a mean score of 2.74 , on a five point scale, indicating a positive level of satisfaction. As mentioned earlier, the standard 5-8 category had the highest mean score of 3.36 overall satisfactions. This positive result may appear to support the concept of the "zone of tolerance" or the extent to which customers recognize and are willing to accept the variations in service quality. In addition, those who preferred shopping in Dukas indicated that while some convenience shops (Dukas) owners (depending on the relationship) could extend credit to them, this was not possible with the supermarkets. The convenience shops (Dukas) also broke bulk further than the supermarkets could. For instance, they could stock $1 / 4 \mathrm{~kg}$ sugar, $1 / 2 \mathrm{~kg}$ maize and wheat flour, Blue band for Ksh. 5, drinking chocolate for Ksh. 5, among others.

The probability of recommending a friend to a convenience shop (kiosk/duka) had an overall mean score of 3.03 indicating that majority of shoppers would recommend a friend to buy from a kiosk/duka. Using Pearson correlation (Table 9) showed that there was a significant positive correlation between the level of satisfaction and recommendation (at 0.01 level-two tailed). This is explained with a 99\% confidence level. The level of education also had a positive correlation with the income. This is explained by a 99\% confidence level at 0.01 level-two tailed. Gender had also a positive relationship with income (i.e. males, (coded as 2) had a general higher income than females (coded as 1). This is explained by a $95 \%$ confidence level (0.05-two tailed). Age showed no relationship with any of the factors hence no influence on the preference levels.

Various recommendations were made in relation to improvements of kiosk/duka services which included (arranged in order of importance): (1) Have variety of products; (2) Reduce prices; (3) Improve on customer care and relations; (4) Improve on in-store and environment; (5) Improve on shop presentation and arrangement; (6) Improve on operating hours to increase accessibility; (7) Cleanliness and security around the shop; and (8) Improve on record keeping. Others included; right location, packing goods in small and convenience packs, better ventilation, and provide receipts for customer account ability.

\subsection{Theoretical Contributions}

The results of the analyses show that the main determinants of service quality within MSEs are tangibles responsiveness 
and reliability in that order while within the supermarkets, the main determinants are Reliability, Responsiveness Empathy and Tangibles in that order. This indicates that different service factor structures have been found in Kenya in relation to the order of importance compared to the USA where Parasuraman et al $(1989 ; 1991)$ carried out their survey. The findings also indicate a lot of similarities on important factors perceived by the two categories of consumers in Kenya. That is, the service quality dimensions of supermarkets and small convenience shops are not perceived differently in Kenya. However, results do indicate that supplying customers with deep assortment, varying prices for various sizes, cleanliness and security are critical in delivering good service quality in small convenience shops and supermarkets.

\section{Conclusion}

The findings from this study have significant implications for both the small convenience shops and the supermarkets in terms of competitive strategies based on shoppers' perceptions.

\subsection{Competitive Strategies for Convenience Shops (Kiosk/Dukas)}

Based on important factors identified above, the competitive strategies of small convenience shops in Kenya might be to concentrate on skills to solve customers' problems, improving on the physical facilities and displays, willingness to assist or in helping the customer, providing variety and deep assortment and improvement in cleanliness. This coincides with customers suggestions for improvement such as provide variety of products, reduce prices, improve on customer care and relations, and improve on in-store and environment; and improvements on shop presentation and arrangement. The small convenience stores owners should determine whether they are allocating their efforts in these areas that are considered important by the shoppers. Due to poor economic conditions in Kenya and the fact that half of Kenya's population is living below the poverty line, repacking of goods into affordable sizes should also be emphasized. In addition, cleanliness and better ventilation should not be overlooked due to many cases of contagious diseases in Kenya such as tuberculoses (TB).

\subsection{Competitive Strategies for Supermarkets}

The supermarkets competitive strategies, based on shoppers perceptions are staff training on courtesy, improvements in physical facilities and displays, keeping accurate records, providing individualized attention and having competent staff.

\section{Policy Recommendations}

The study shows that majority of people have positive perception of small convenience shops (with overall mean score of 3.03). The following interventions are necessary for enhancing small convenience shops competitiveness;

1. Facilitate service quality and customer care training within convenience shops- A flexible training on service quality coupled with role playing should be developed by both formal and Micro Small Enterprises (MSE) training providers to enhance convenience shops competitiveness. A training manual of service quality and customer care could be developed in a simple language and disseminated to the small shop owners and their trainers. Convenience shops owners should also be trained on in-store arrangement of products, appropriate displays and cleanliness. Record keeping and customer databases should be emphasized in the training.

2. Promote security around convenience shops- Promotion of security would allow the convenience shops to operate for longer hours and thus provide customer with the convenience they need.

3. Promote convenience shops' association/groups buying centers- The government and leadership structures of small convenience shops should encourage formation of buying associations. These should be well organized good/product buying association or group. They would enable the small convenience shops to buy goods in bulk and get quantity discounts; as well as buy variety of products and sizes. This would enable them to price their products competitively and provide variety of products to customers.

\section{Suggestions for Further Research}

Since this research was pilot in nature and concentrated on only two sub-urban areas of Nairobi, it is important to widen the scope of this study both geographically and sample-wise to allow for generalization of the findings. With great expansion of supermarkets in Kenya, witnessed by divided loyalty across various supermarkets, it is important to determine why consumers divide their purchases across different supermarkets that apparently stock similar goods. 


\section{Acknowledgments}

We wish to thank the administration of Ongata Rongai and Ngong for facilitating this research. Our sincere gratitude goes to the respondents who generously provided us with the data. We wish to acknowledge the useful feedback and contribution we got when the paper was presented at an international conference at the United States International University (USIU)-Kenya. Our sincere thanks also go to Edwin Wayande who did the analysis of the data.

\section{References}

Bitner, M. J., \& Hubbert, A. R. (1994). Encounter satisfaction versus overall satisfaction versus quality: the customer voice. In Rust, R. T. and Oliver, R. L. (Eds), Service Quality: New directions in theory and Practice, sage, Thousand Oaks, CA, pp 72-94.

Berman, B., \& Evans, J. R. (2005). Retailing Management. A strategic Approach. Prentice hall. USA.

Bougoure, U., \& Lee, B. (2009). Service quality in Hong Kong: wet markets vs supermarkets. British Food Journal. Vol. 111, No. 1, pp. 70-79. http://dx.doi.org/10.1108/00070700910924245

Dabholka, A. P., Thorpe, P. A., \& Rentz, J. O. (1996). A measure of service quality for retail stores: scale development and validation. Journal of the Academy of Marketing Science. Vol. 24 No.1 pp. 3-16. http://dx.doi.org/10.1007/BF02893933

Economic Survey. (2010). Kenya National Bureau of statistics. Nairobi.

Easterby-Smith, M., Thorpe, P., \& Lowe, A. (1991). Management Research: An introduction. Sage publication, Newbury Park, CA.

Finn, D. (2004). How information power can improve service quality. Planning review. Vol. 19. No.3 pp. 24-26.

Gagliano, K. B., \& Hathcote, J. (1994). Customer expectations and perceptions of service quality in Retail apparel Specialty Stores. Journal of Service marketing. Vol $8 . \quad$ No. $1 . \quad$ pp. 60-69. http://dx.doi.org/10.1108/08876049410053311

Gronroos, C. (2001). The Perceived Service Quality Concept-A Mistake. Managing Service Quality. Vol.11, No. 3, 2001, pp. 150-152. http://dx.doi.org/10.1108/09604520110393386

Kagira, E. K., \& Kimani, S. W. (2010). Marketing Principles and Practices: An African Perspective. Nairobi. Mashel Publishers.

Kotler, P., \& Keller, K. (2006). Marketing Management. $12^{\text {th }}$ Edition. Upper saddle River, NJ. Pearson. Prentice Hall.

Naylor, G. \& Frank, K. E. (2000). The impact of retail sales force responsiveness on consumers' perception of Value. Journal of Service Marketing. Vol 14. No. 4. pp. 310-322. http://dx.doi.org/10.1108/08876040010334529

Nguyen, D. D. N., \& Le Nguyen, H. (2007). Determinants of retail service quality: A study of Supermarkets in Vietnam. TAP CHI PHAT TRIEN KH\&CN,TAP 10, SO.

Parasuraman, A., Zeithaml, V., \& Berry, L. (1988). SERVQUAL: A multiple item scale for measuring consumer perception of service quality. Journal of Retailing. Vol. 64 pp.12-40.

Rust R.T., Danaher, P.J., \& Sajeev. (2000). Using Service Quality Data for Competitive Marketing Decisions. International Journal of services Industry Management. Vol.11 No.5 pp. 438-469. http://dx.doi.org/10.1108/09564230010360173

Ryu, K., \& Han, H. (2010). Influence of the quality of food, service and physical environment on Customer Satisfaction and Behavioural intention in quick-casual restaurants: moderating role of perceived price. Journal of Hospitality \& Tourism Research. Vol.34. No.3. pp. 310-329. http://dx.doi.org/10.1177/1096348009350624.

Shaw, D., \& Haynes, B. (2004). An Evaluation of consumer Perception of FM service delivery. Journal of Facilities. Vol.22. No. 7/8. pp.170-177. http://dx.doi.org/10.1108/02632770410547534.

Sheinin, D. A., \& Wagner, J. (2003). Pricing store brands across categories and retailers. Journal of product and brand management. Vol. 12. No. 4. pp. 210-219. http://dx.doi.org/10.1108/10610420310485023.

Strickland, L. (2008). Customer satisfaction: Perception of product and service quality. F.O.C.U.S. Resources. http://carolinanewswire.com

Tan, W. C. M., \& Mehta, S. C. (1994). Merchandise Vs. Facility-Driven services: Relative role in consumer choice of supermarkets in Singapore. Asia Pacific Advances in Consumer Research. Vol. 1 pp 160-164.

Vilares, M. J., \& Coelho, P. S. (2003). The employee-customer satisfaction chain in the ECSI model. European Journal of Marketing. Vol. 37 Iss: 11/12, pp.1703-1722. http://dx.doi.org/10.1108/03090560310495429.

Wang, S. (2003). A review of the Service Quality Scales of Retail Stores. School of Medicine and Health Management, Hangzhou Normal University, P.R. China, 310036. 
Watkins, E. (1976). Customer Analysis and Market Strategy-Supermarkets vs, Convenience stores. Journal of Food Distribution Research. pp 110-113.

Zeithaml, V. A., Parasuraman, A. \& Berry, L. (1988). Communication and Control Processes in the Delivery of services. Journal of Marketing. Vol. 52 pp.36-58. http://dx.doi.org/10.2307/1251263.

Zeithaml, V., \& Bitner, M. J. (2009). Services Marketing: Integrating Customer Focus Across the Firm. 3rd Ed. Boston: McGraw-Hill.

Table1. General factors considered important in shopping

\begin{tabular}{|c|c|c|}
\hline No. & Factor & Average number per 100 customers \\
\hline 1 & Variety & 72 \\
\hline 2 & Convenience & 69 \\
\hline 3 & Good communication to customers & 59 \\
\hline 4 & Less expensive/cheap prices & 57 \\
\hline 5 & Quick or prompt service & 54 \\
\hline 6 & Reliability and consistency of service and products & 51 \\
\hline 7 & Deep assortment of products & 45 \\
\hline 8 & Courtesy and friendliness & 43 \\
\hline 9 & Honest, trust and confidence & 39 \\
\hline 10 & Access or ease of approach and contact & 30 \\
\hline
\end{tabular}

Table 2. Specific factors considered important by customers of convenience shops arranged in order of importance

\begin{tabular}{|c|c|c|}
\hline No. & Factor & Loading \\
\hline 1 & Ability to solve problems & 0.854 \\
\hline 2 & Physical facilities and displays & 0.839 \\
\hline 3 & Assistance/helping the customer & 0.828 \\
\hline 4 & Variety and deep assortment & 0.803 \\
\hline 5 & Cleanliness & 0.795 \\
\hline 6 & Accurate records & 0.774 \\
\hline 7 & Responsiveness & 0.769 \\
\hline 8 & Appearance & 0.754 \\
\hline 9 & Individualized attention & 0.724 \\
\hline 10 & Convenience & 0.717 \\
\hline
\end{tabular}

Table 3. Specific factors considered important by customers of supermarkets arranged in order of importance

\begin{tabular}{|c|c|c|}
\hline No. & Factor & Loading \\
\hline 1 & Courtesy & 0.831 \\
\hline 2 & Physical facilities and displays & 0.785 \\
\hline 3 & Accurate records & 0.770 \\
\hline 4 & Individualized attention & 0.768 \\
\hline 5 & Competence & 0.762 \\
\hline 6 & Keeping promises & 0.755 \\
\hline 7 & Variety and deep assortments & 0.720 \\
\hline 8 & Prompt service & 0.658 \\
\hline 9 & Neat appearance & 0.652 \\
\hline 10 & Accessibility & 0.590 \\
\hline
\end{tabular}


Table 4. Communities

Table 5. Total variance explained

\begin{tabular}{|c|c|c|}
\hline & Initial & Extraction \\
\hline Q51A & 1.000 & 0.547 \\
\hline Q52A & 1.000 & 0.746 \\
\hline Q53A & 1.000 & 0.699 \\
\hline Q54A & 1.000 & 0.652 \\
\hline Q55A & 1.000 & 0.670 \\
\hline Q56A & 1.000 & 0.533 \\
\hline Q57A & 1.000 & 0.606 \\
\hline Q58A & 1.000 & 0.751 \\
\hline Q59A & 1.000 & 0.657 \\
\hline Q10A & 1.000 & 0.676 \\
\hline Q11A & 1.000 & 0.598 \\
\hline Q12A & 1.000 & 0.442 \\
\hline Q13A & 1.000 & 0.413 \\
\hline Q14A & 1.000 & 0.511 \\
\hline
\end{tabular}

\begin{tabular}{|c|c|c|c|c|c|c|c|c|c|}
\hline Component & \multicolumn{3}{|c|}{ Initial Eigenvalues } & \multicolumn{2}{c|}{$\begin{array}{c}\text { Extraction Sums of Squared } \\
\text { Loadings }\end{array}$} & \multicolumn{3}{c|}{$\begin{array}{c}\text { Rotation Sums of Squared } \\
\text { Loadings }\end{array}$} \\
\cline { 2 - 10 } & Total & $\begin{array}{c}\text { \% of } \\
\text { Variance }\end{array}$ & $\begin{array}{c}\text { Cumulative } \\
\%\end{array}$ & Total & $\begin{array}{c}\text { \% of } \\
\text { Variance }\end{array}$ & $\begin{array}{c}\text { Cumulative } \\
\%\end{array}$ & Total & $\begin{array}{c}\text { \% of } \\
\text { Variance }\end{array}$ & $\begin{array}{c}\text { Cumulativ } \\
\text { e \% }\end{array}$ \\
\hline 1 & 5.880 & 5.880 & 42.002 & 5.880 & 42.002 & 42.002 & 3.670 & 26.212 & 26.212 \\
\hline 2 & 1.466 & 10.468 & 52.470 & 1.466 & 10.468 & 52.470 & 3.343 & 23.881 & 50.094 \\
\hline 3 & 1.154 & 8.240 & 60.710 & 1.154 & 8.240 & 60.710 & 1.486 & 10.617 & 10.617 \\
\hline 4 & 0.980 & 7.002 & 67.713 & & & & & & \\
\hline 5 & 0.831 & 5.933 & 73.646 & & & & & & \\
\hline 6 & 0.803 & 5.733 & 79.379 & & & & & & \\
\hline 7 & 0.672 & 4.802 & 84.180 & & & & & & \\
\hline 8 & 0.544 & 3.887 & 88.068 & & & & & & \\
\hline 9 & 0.435 & 3.107 & 91.175 & & & & & & \\
\hline 10 & 0.329 & 2.352 & 93.527 & & & & & & \\
\hline 11 & 0.288 & 2.059 & 95.586 & & & & & & \\
\hline 12 & 0.269 & 1.922 & 97.507 & & & & & & \\
\hline 13 & 0.219 & 1.564 & 99.071 & & & & & & \\
\hline 14 & 0.929 & 100.000 & & & & & & & \\
\hline
\end{tabular}

Table 6. Rotated component Matrix(a)

\begin{tabular}{|c|c|c|c|}
\hline \multirow{2}{*}{} & \multicolumn{3}{|c|}{ Component } \\
\cline { 2 - 4 } & 1 & 2 & 3 \\
\hline Q51A & 0.674 & 0.302 & 0.044 \\
\hline Q52A & 0.794 & 0.297 & 0.165 \\
\hline Q53A & 0.826 & 0.079 & 0.097 \\
\hline Q54A & 0.670 & 0.221 & 0.393 \\
\hline Q55A & 0.452 & 0.512 & 0.451 \\
\hline Q56A & 0.509 & 0.180 & 0.492 \\
\hline Q57A & 0.387 & 0.672 & 0.074 \\
\hline Q58A & 0.152 & 0.838 & 0.161 \\
\hline Q59A & 0.101 & 0.788 & 0.160 \\
\hline Q510A & 0.186 & 0.753 & 0.273 \\
\hline Q511A & 0.409 & 0.567 & 0.330 \\
\hline Q512A & 0.525 & 0.344 & 0.219 \\
\hline Q513A & 0.575 & 0.086 & 0.274 \\
\hline Q514A & 0.010 & 0.160 & 0.696 \\
\hline
\end{tabular}


Table 7. Total variance explained

\begin{tabular}{|c|c|c|c|c|c|c|c|c|c|}
\hline Component & \multicolumn{3}{|c|}{ Initial Eigenvalues } & \multicolumn{3}{c|}{$\begin{array}{c}\text { Extraction Sums of Squared } \\
\text { Loadings }\end{array}$} & \multicolumn{3}{c|}{$\begin{array}{c}\text { Rotation Sums of Squared } \\
\text { Loadings }\end{array}$} \\
\cline { 2 - 10 } & Total & $\begin{array}{c}\text { \% of } \\
\text { Variance }\end{array}$ & $\begin{array}{c}\text { Cumulative } \\
\%\end{array}$ & Total & $\begin{array}{c}\text { \% of } \\
\text { Variance }\end{array}$ & $\begin{array}{c}\text { Cumulative } \\
\%\end{array}$ & Total & $\begin{array}{c}\text { \% of } \\
\text { Variance }\end{array}$ & $\begin{array}{c}\text { Cumulative } \\
\%\end{array}$ \\
\hline 1 & 5.211 & 37.223 & 37.223 & 5.211 & 37.223 & 37.223 & 2.811 & 20.080 & 20.080 \\
\hline 2 & 1.414 & 10.102 & 47.325 & 1.414 & 10.102 & 47.325 & 2.468 & 17.630 & 37.710 \\
\hline 3 & 1.271 & 9.081 & 56.407 & 1.271 & 9.081 & 56.407 & 2.081 & 14.862 & 52.572 \\
\hline 4 & 1.107 & 7.906 & 64.313 & 1.107 & 7.906 & 64.313 & 1.644 & 11.740 & 64.313 \\
\hline 5 & 0.941 & 6.718 & 71.031 & & & & & & \\
\hline 6 & 0.773 & 5.520 & 76.550 & & & & & & \\
\hline 7 & 0.641 & 4.580 & 81.131 & & & & & & \\
\hline 8 & 0.614 & 4.387 & 85.518 & & & & & & \\
\hline 9 & 0.555 & 3.965 & 89.483 & & & & & & \\
\hline 10 & 0.502 & 3.587 & 93.070 & & & & & & \\
\hline 11 & 0.364 & 2.602 & 95.672 & & & & & & \\
\hline 12 & 0.304 & 2.174 & 97.846 & & & & & & \\
\hline 13 & 0.200 & 1.427 & 99.273 & & & & & & \\
\hline 14 & 0.102 & 0.727 & 100.000 & & & & & & \\
\hline
\end{tabular}

Table 8. Rotated component matrix (a)

\begin{tabular}{|c|c|c|c|c|}
\hline \multirow{2}{*}{} & \multicolumn{4}{|c|}{ Component } \\
\cline { 2 - 5 } & 1 & 2 & 3 & 4 \\
\hline Q515A & 0.762 & 0.196 & 0.195 & 0.153 \\
\hline Q516A & 0.726 & 0.062 & 0.118 & 0.566 \\
\hline Q517A & 0.278 & 0.236 & 0.029 & 0.843 \\
\hline Q518A & 0.139 & 0.634 & 0.245 & 0.301 \\
\hline Q519A & 0.079 & 0.836 & 0.137 & 0.250 \\
\hline Q520A & 0.361 & 0.780 & 0.085 & 0.050 \\
\hline Q521A & 0.452 & 0.452 & 0.044 & 0.111 \\
\hline Q522A & 0.189 & 0.384 & 0.504 & 0.136 \\
\hline Q523A & 0.054 & 0.337 & 0.704 & 0.043 \\
\hline Q524A & 0.008 & 0.158 & 0.615 & 0.591 \\
\hline Q525A & 0.438 & 0.045 & 0.606 & 0.076 \\
\hline Q526A & 0.366 & 0.088 & 0.611 & 0.029 \\
\hline Q527A & 0.603 & 0.245 & 0.257 & 0.102 \\
\hline Q528A & 0.734 & 0.318 & 0.082 & 0.184 \\
\hline
\end{tabular}


Table 9. Correlation

\begin{tabular}{|c|c|c|c|c|c|c|c|}
\hline & & Q6 & Q7 & Education & Income & Age & Gender \\
\hline \multirow{3}{*}{$\begin{array}{l}\text { Q6 (Level of } \\
\text { satisfaction) }\end{array}$} & Pearson Correlation & 1 & $0.419(* *)$ & -0.152 & -0.224 & -0.227 & -0.067 \\
\hline & Sig.(2-tailed) & & 0.000 & 0.209 & 0.062 & 0.059 & 0.582 \\
\hline & $\mathrm{N}$ & 70 & 69 & 70 & 70 & 70 & 70 \\
\hline \multirow{3}{*}{$\begin{array}{c}\text { Q7 (Level of } \\
\text { recommendation) }\end{array}$} & Pearson Correlation & $0.419(* *)$ & 1 & -0.028 & 0.125 & 0.084 & 0.013 \\
\hline & Sig.(2-tailed) & 0.000 & & 0.817 & 0.307 & 0.491 & 0.918 \\
\hline & $\mathrm{N}$ & 69 & 69 & 69 & 69 & 69 & 69 \\
\hline \multirow[t]{3}{*}{ Education } & Pearson Correlation & -0.152 & -0.028 & 1 & $0.452(* *)$ & 0.154 & 0.223 \\
\hline & Sig.(2-tailed) & 0.209 & 0.817 & & 0.000 & 0.191 & 0.056 \\
\hline & $\mathrm{N}$ & 70 & 69 & 74 & 74 & 74 & 74 \\
\hline \multirow[t]{3}{*}{ Income } & Pearson Correlation & -0.224 & 0.125 & $0.452(* *)$ & 1 & 0.213 & $0.261(*)$ \\
\hline & Sig.(2-tailed) & 0.062 & 0.307 & 0.000 & & 0.069 & 0.025 \\
\hline & $\mathrm{N}$ & 70 & 69 & 74 & 74 & 74 & 74 \\
\hline \multirow[t]{3}{*}{ Age } & Pearson Correlation & -0.227 & 0.084 & 0.154 & 0.213 & 1 & 0.105 \\
\hline & Sig.(2-tailed) & 0.059 & 0.491 & 0.191 & 0.069 & & 0.375 \\
\hline & $\mathrm{N}$ & 70 & 69 & 74 & 74 & 74 & 74 \\
\hline \multirow[t]{3}{*}{ Gender } & Pearson Correlation & -0.067 & 0.013 & 0.223 & $0.261(*)$ & 0.105 & 1 \\
\hline & Sig.(2-tailed) & 0.582 & 0.918 & 0.056 & 0.025 & 0.375 & \\
\hline & $\mathrm{N}$ & 70 & 69 & 74 & 74 & 74 & 74 \\
\hline
\end{tabular}

**Correlation is significant at 0.01 level (2-tailed)

* Correlation is significant at the 0.05 level (2-tailed) 